\title{
Prevention and Reduction of Geological and Environmental Problems in the Iranian Cities by Development of Geoscientific Knowledge-Base and Cyber-Infrastructure in the Urban Scale
}

\author{
Mohsen Ehteshami-Moinabadi* \\ Department of Sedimentary Basins and Petroleum, Shahid Beheshti University, Iran
}

*Corresponding author: Mohsen Ehteshami-Moinabadi, Department of Sedimentary

Basins and Petroleum, Shahid Beheshti University, Iran.
Received Date: April 04, 2019

Published Date: April 30, 2019

\begin{abstract}
Fast urbanization and growing urban areas pose great problems in water, energy waste, environment and geohazards of developing countries, as well as Iran. Many of these problems are related to issues that linked with geo-environmental constrains inside or around the cities directly or indirectly. urban geoscience in general and urban geology in particular are growing disciplines that provide essential knowledge for better understanding of geo environmental characteristics of urban areas in the large scales. The sound effectiveness of this knowledge requires the implementation of urban geoscientific cyber-infrastructures and knowledge-bases in the megacities. 3D-modeling, integration and other computational capabilities of modern days computing systems for huge amount of geospatial data in urban environment is an important and required tool to being prepared against challenges in the megacities as well as fast developing urban areas. This paper highlights major challenges of megacities in Iran that can be addressed by implementation of geoscientific cyber-infrastructure and knowledge-base.
\end{abstract}

Keywords: Big data; Knowledge-base; Urban geology; Megacities; Geoscience

\section{Introduction}

The fast urbanization has been continuing in many developing countries in world without required precautions in the longterm, considering the costs might appear in the future due to the fast urbanization [1]. Low attention to geological phenomena in the built environment is the source of many problems in near to mid-time in many cities and studies on geological aspects of urban environments is a major step to recognize and combat against the future problems [2-5]. Knowledge-based decision-making at all steps needs the accessibility and reliability of information and knowledge to be enhanced by establishment of collaborative cyber-infrastructures and ontologies for geosciences [6]. Based on last Population and Housing Censuses of Iran at 2016, more than $73 \%$ of people live in urban environments in Iran showing $2 \%$ growth of urban population than 2011 [7]. There is an increasing trend in number and dimensions of problems or crisis due to geological, environmental and climate-change phenomena in the urban populations of Iran during last decades [8-11]. This is more significant in ten megacities of Iran. This paper is of first attempts to the state of art of previous works done by governmental organization of IR Iran on implementation of national databases and information system for geosciences.

From Data to Knowledge in Geospatial and Geological Contexts

The DIKW hierarchy (Data, Information, Knowledge, Wisdom) was presented by Sharma [12] highlighting the first appearances of the hierarchy in both the knowledge management and information science domains [13] (Figure 2). In this hierarchy, computational methods play a major role in the initial processing of data to extract information, but they alone become less effective to compile knowledge from information [14]. Another form of representation of this concept is DIKW pyramid (Figure 2) that is more acceptable near information scientists [15] (Figure 1). 
context

independence

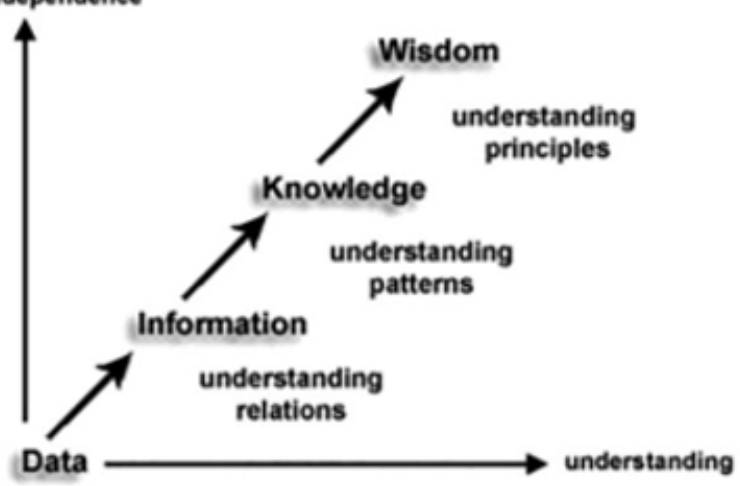

b

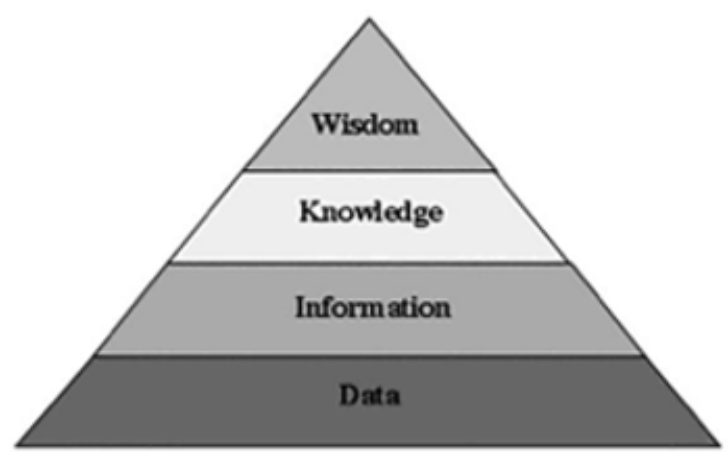

Figure 1: DIKW hierarchy (left) and DIKW pyramid (right).

According to Schreiber [16] and Nickols [17] geological knowledge can be categorized (Figure 2) as:

1. Explicit - knowledge that has been recorded, communicated or expressed in some sensible way;
2. Implicit - knowledge that is capable of being communicated or expressed, but is yet to be made explicit;
3. Tacit - knowledge that cannot be expressed but is obtained and exchanged by experience-based learning (Figure 2).

\section{The Geoscience Knowledge-Tree}

\section{Geoscience data}

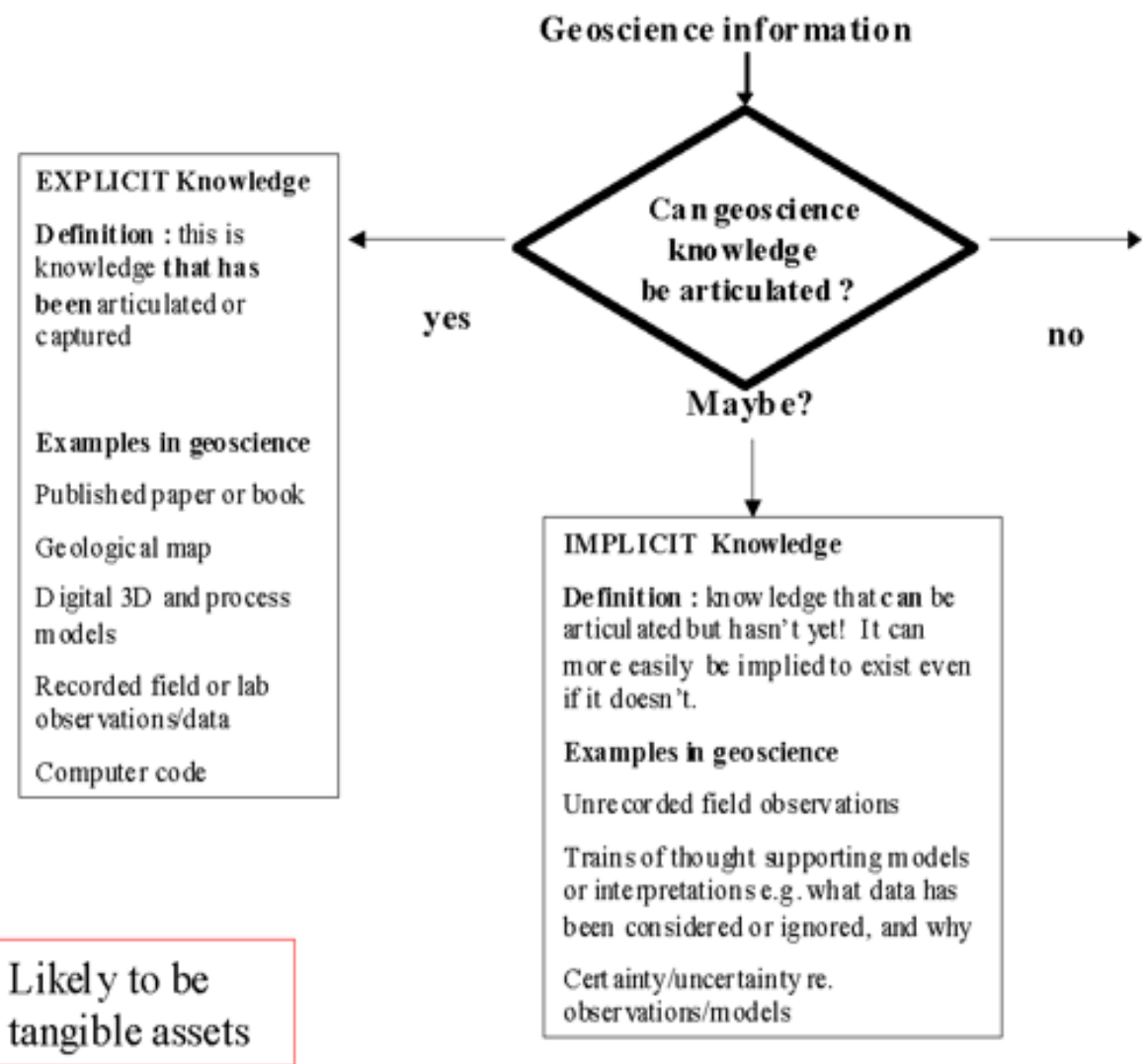

TAC IT Knowledge

Definition : this is knowledge that cannot be articulated. The knowing is in the doing! Examples in geoscience

Experience in analysis e.g seismic/petr ophysical interpr etation

Spatial judgem ent - e.g. geo logy of under ground or open pit mine design

\section{Likely to be less} tangible assets

\section{Increasing difficulty to formalise}

Figure 2: Definitions of explicit, implicit and tacit knowledge, with examples from geosciences (Modified from Howard et al. 2009). 
State of Art of National Geospatial, Geological, Environmental Databases in Iran

The Producers of geological and geospatial data are completely diverse in size, subjects, occupation across the country. Beside the private sector acting on mineral industry, consulting engineers, geotechnical and civil division and so on; major, but not all, governmental organizations include Geological Survey of Iran, National Iranian Oil Company (NIOC), National Cartographic Center (NCC), National Geography Organization of Iran (NGOI), Ministry of Power, Ministry of Industry, Mine, Trade and many other ones. Among these organizations some have implemented relatively welldeveloped datacenters or spatial data infrastructures such as NCC, NIOC and NGOI. One the successful examples of implementation a national datacenter for geological and geospatial data and information by governmental organizations was started at 2001 in the Geological Survey of Iran entitled The National Geoscience Database of Iran (NGDIR). During 14 years of activity, the NGDIR was rare national database in the Middle East that put a vast effort on systematically implementation of geoscientific database on more than 20 topics including geological maps, earthquake, geotechnics, geochemistry, mines, etc. Many of databases were designed and implemented via getting advice or under direct conduction of top experts from various universities across the country. Unfortunately, and sadly, during recent years, due to less attention, management and financial issues the NGDIR has diminished to a great extent and has been forgotten. This not good for no one of us because of a great support for better research is and also better response to management needs to up to date information (Figure 3).
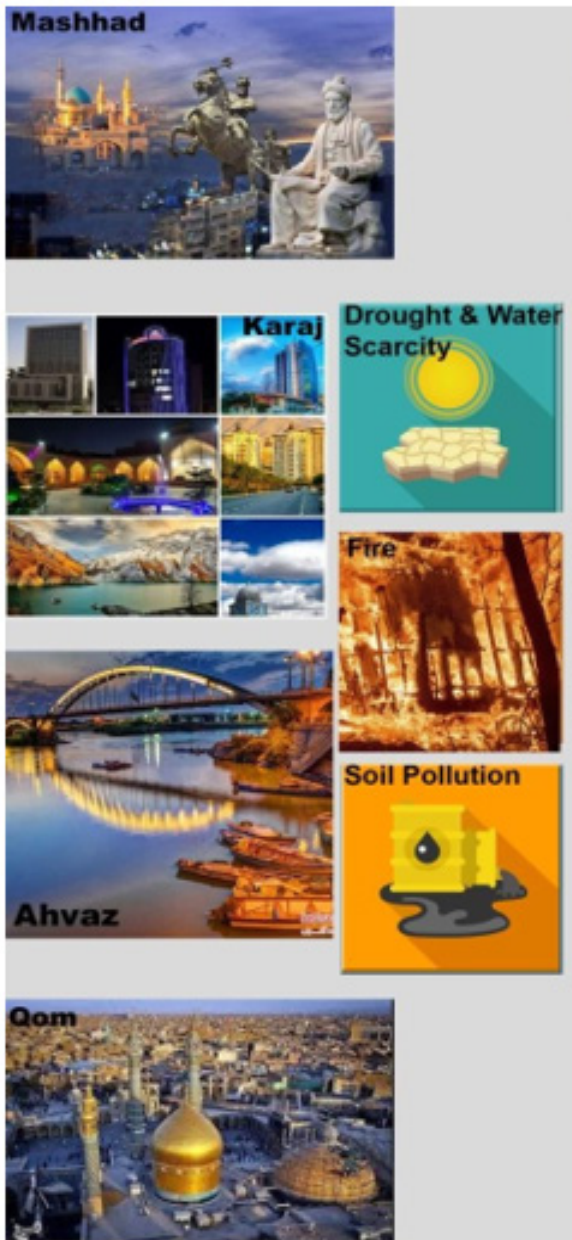
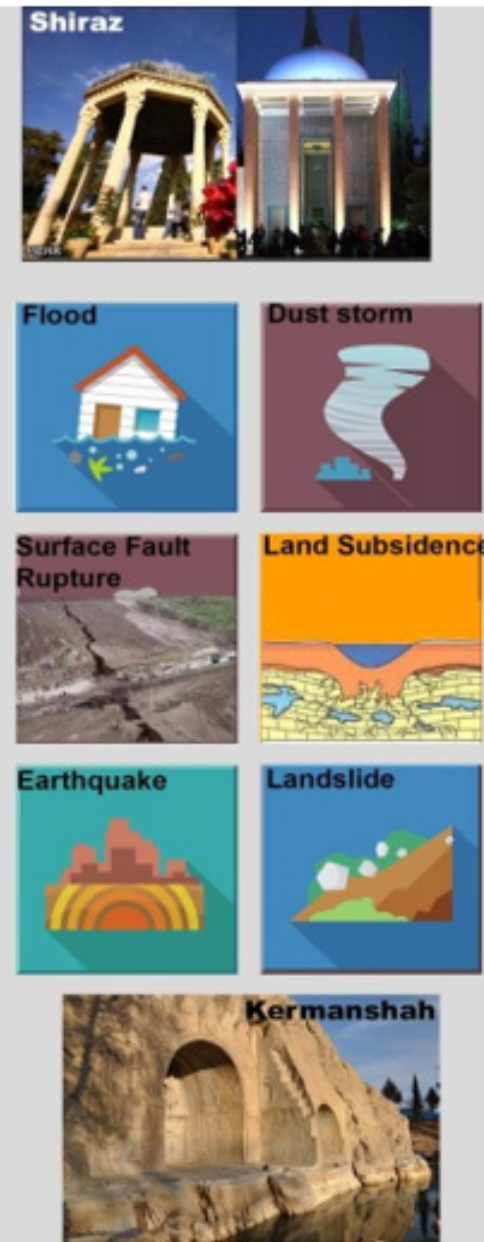

Land Subsidence

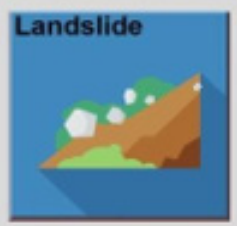

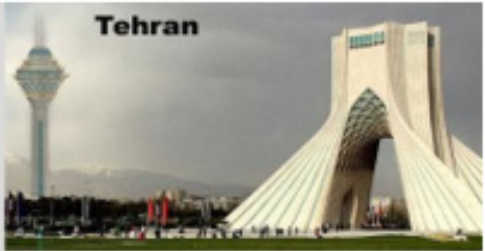
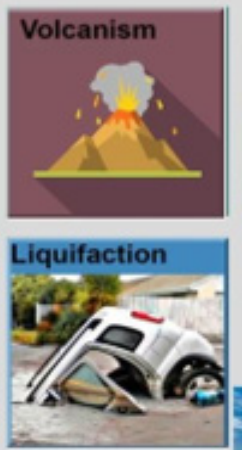

Air Pollution
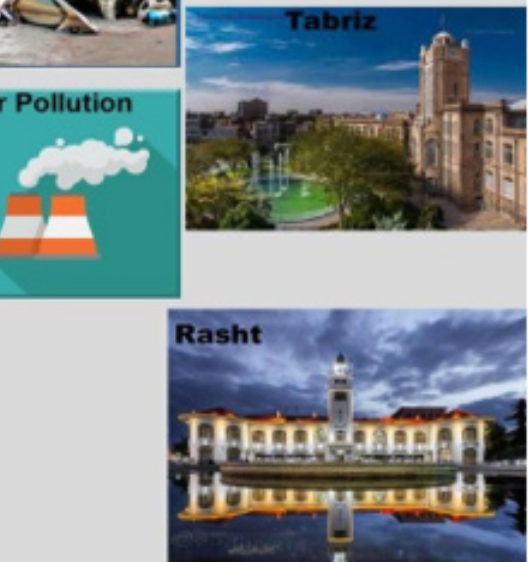

Figure 3: Infographic presentation of major geo-environmental problems and challenges of ten megacities of Iran.

\section{Challenges for urban managers}

Numerous studies discussed major problems in the urban environments of Iran (Figure 3) that include but not complete:

1. Waste management involving solid waste management [18], wastewater management [19], Medical wastes and hospital wastes [20]

2. Geohazard risk and crisis management involving urban flood management [39], earthquake hazard [22], surface fault rupture (e.g. Ehteshami-Moinabadi, 2015; 2016), land subsidence in urban areas [23-25]

3. Urban ecology [26] air pollution, voice pollution,

\section{Transportation and traffic}

These problems are highlighted due to management issues and some factors such as fragmentation of responsibilities and roles, multiplicity of actors, lack of inter-sectoral coordination and public participation [27]. Although these challenges are important 
in Iran, but many of them also cause significant problems in other megacities around the world. For example, water resources management [28,29] and integrated water management in megacities [30] coastal megacities [31,32]; energy demand [33], environmental challenges [34], and natural disasters [35-37].

\section{Discussion and Conclusion}

Earth science and specially geology is the study of the Earth's structure and history. It supports the provision of resources to human populations and brings a wide range of essential services to them and industry and helps to understand how we can live sustainably on the Earth. The Earth is a dynamic planet with many dynamic phenomena and forces acting on land surface, water bodies, atmosphere and hundreds of kilometers below its crust. The fast urbanization in many developing countries in the world without required precautions, will intake considerable socioeconomic costs in the long-term [1]. Experiences from around the world recommend the development of geoscientific knowledge-base and cyber-infrastructure in the urban scale as tool to being prepared against challenges in the megacities as well as fast developing urban areas [38-45]. According to the previous practical developments of large scale geoscientific database in Iran, development of largescale databases, knowledge-bases and cyber-infrastructures for megacities isanimportant toolas well as step for better managements of megacities that provides opportunities for interaction among various information, prediction of risks and estimation of damages due to scenario natural hazards, implementation of early warning systems in public areas and fast alarm system for urban managers, proving a basement for sub-surface 3D modeling of underground urban area and et cet. Understanding and modelling of urban environments by technological development of 3D city-scale ground models and our multi-thematic spatial datasets can be used across the environmental, planning and insurance sectors. These systems can address solutions for water-resource management, geohazard-resilience and planning challenges such as assessing ground conditions and risks to urban infrastructure [46]. Data types and information layers applicable for development of urban geoscientific data-infrastructures are defined in detail in Ehteshami-Moinabadi [47], Culshaw and Price [48] and Reeves [46]. There are some issues or challenges for implementation of such infrastructures that should be addressed before. Security issues, law conflicts $[49,50]$.

\section{Acknowledgement}

None.

\section{Conflict of Interest}

No conflict of interest.

\section{References}

1. Kumlu KBY, Tüdes S (2018) Multi Criteria Decision Making Techniques in Urban Planning and Geology. In Handbook of Research on Trends and Digital Advances in Engineering Geology IGI Global, pp.530-568.

2. Mejía-Navarro M, Wohl EE, Oaks SD (1994) Geological hazards, vulnerability, and risk assessment using GIS: model for Glenwood Springs, Colorado. In Geomorphology and Natural Hazards pp.331-354.
3. Edbrooke SW, Mazengarb C, Stephenson W (2003) Geology and geological hazards of the Auckland urban area, New Zealand. Quaternary International 103(1): 3-21.

4. Fernández DS, Lutz MA (2010) Urban flood hazard zoning in Tucumán Province, Argentina, using GIS and multicriteria decision analysis. Engineering Geology 111(1-4): 90-98.

5. Huang L, Yan L, Wu J (2016) Assessing urban sustainability of Chinese megacities: 35 years after the economic reform and open-door policy. Landscape and Urban Planning 145: 57- 70.

6. Howard AS, Hatton B, Reitsma F, Lawrie KI (2009) Developing a geoscience knowledge framework for a national geological survey organization. Computers \& Geosciences 35(4): 820-835.

7. Statistical Center of Iran (2017) Selection of the results of general census of population and housing of Iran, 2016. 50 p. Report No 4901. Statistical Center of Iran

8. Atapour H, Aftabi, A (2002) Geomorphological, geochemical and geoenvironmental aspects of karstification in the urban areas of Kerman city, southeastern, Iran. Environmental Geology 42(7): 783-792.

9. Nasrabadi T, Abbasi M (2014) Groundwater quality degradation of urban areas (case study: Tehran city, Iran) International Journal of Environmental Science and Technology 11(2): 293-302.

10. Azarafza M, Ghazifard A (2016) Urban geology of Tabriz City: Environmental and geological constraints. Advances in Environmental Research (AER): An International Journal 5(2): 95-108.

11. Karbasi A, Khoramnezhadian S, Zavareh SRA, Sani GP (2018) Determination of the emission rate and modeling of benzene dispersion due to surface evaporation from an oil pit. Journal of Air Pollution and Health 3(3): 155-166.

12. Sharma N (2004) The origin of DIKW Hierarchy. Go.webassistant.com

13. Hey J (2004) The data, information, knowledge, wisdom chain: the metaphorical link. Intergovernmental Oceanographic Commission 26: $1-18$.

14. Kanehisa M, Goto S, Sato Y, Kawashima M, Furumichi M, Tanabe M (2013) Data, information, knowledge and principle: back to metabolism in KEGG. Nucleic acids research 42(D1): D199-D205.

15. Frické, M (2009) The knowledge pyramid: a critique of the DIKW hierarchy. Journal of information science 35(2): 131-142.

16. Schreiber G, Akkermans H, Anjewierden A, de Hoog R, Shadbolt N, et al. (2000) Knowledge Engineering and Management: The CommonKADS Methodology. The MIT Press, Massachusetts Institute of Technology, USA, p.465.

17. Nickols FW (2000) The knowledge in knowledge management. In: Cortada JW, Woods JA (Eds.) The Knowledge Management Yearbook. Butterworth-Heinemann, Boston, pp. 89-107.

18. Damghani AM, Savarypour G, Zand E, Deihimfard R (2008) Municipal solid waste management in Tehran: Current practices, opportunities and challenges. Waste management 28(5): 929-934.

19. Tajrishy M, Abrishamchi A (2005) Integrated approach to water and wastewater management for Tehran, Iran. In Water Conservation, Reuse, and Recycling: Proceedings of the Iranian-American Workshop.

20. Dehghani MH, Azam K, Changani F, Dehghani Fard E (2008) Assessment of medical waste management in educational hospitals of Tehran university medical sciences.

21. Radmehr A, Araghinejad S (2014) Developing strategies for urban flood management of Tehran city using SMCDM and ANN. Journal of Computing in Civil Engineering 28(6): 05014006.

22. Berberian M, Yeats RS (2017) Tehran: An earthquake time bomb. Tectonic Evolution, Collision, and Seismicity of Southwest Asia: In Honor of Manuel Berberian's Forty-Five Years of Research Contributions 525: 87.

23. Motagh M, Djamour Y, Walter TR, Wetzel HU, Zschau J, Arabi S (2007) Land subsidence in Mashhad Valley, northeast Iran: results from InSAR, levelling and GPS. Geophysical Journal International 168(2): 518-526. 
24. Mohaghegh B, Ehteshami-Moinabadi M, Heydari R (2011) Application of InSAR in Subsidence Monitoring and Analysis, Case Study: Hamadan State of Iran. IUGG Conference, Melbourne Australia.

25. Mahmoudpour M, Khamehchiyan M, Nikudel MR, Ghassemi MR (2016) Numerical simulation and prediction of regional land subsidence caused by groundwater exploitation in the southwest plain of Tehran, Iran. Engineering Geology 201: 6-28.

26. Jafari BBESH, Behbahani HI (2012) Urban ecological landscape planning and design from garden city toward modern city-a case study: Tehran city in Iran.

27. Zamani B, Arefi M (2013) Iranian new towns and their urban management issues: A critical review of influential actors and factors. Cities 30: 105-112.

28. Lundqvist J, Tortajada C, Varis O, Biswas A (2005) Water management in megacities. Ambio 34(3): 267.

29. Biswas AK (2006) Water management for major urban centres. Water Resources Development 22(2): 183-197.

30. Braga BPF (2001) Integrated urban water resources management: a challenge into the $21^{\text {st }}$ century. International Journal of Water Resources Development 17(4): 581-599.

31. Yeung YM (2001) Coastal mega-cities in Asia: transformation, sustainability and management. Ocean \& Coastal Management 44(5-6): 319-333.

32. Li H (2003) Management of coastal mega-cities-a new challenge in the 21st century. Marine Policy 27(4): 333-337.

33. Madlener R, Sunak Y (2011) Impacts of urbanization on urban structures and energy demand: What can we learn for urban energy planning and urbanization management? Sustainable Cities and Society 1(1): 45-53.

34. Lawanson T, Yadua 0, Salako I (2012) Environmental challenges of periurban settlements in the Lagos megacity.

35. Parker D, Mitchell JK (1995) Disaster vulnerability of megacities: an expanding problem that requires rethinking and innovative responses. GeoJournal 37(3): 295-301.

36. Hochrainer S, Mechler R (2011) Natural disaster risk in Asian megacities: A case for risk pooling? Cities 28(1): 53-61.

37. Pelling M, Wisner B (2012) Disaster risk reduction: Cases from urban Africa. Routledge.
38. Novotny V (2008) Sustainable urban water management. In Water and urban development paradigms CRC Press, USA, pp. 37-50.

39.Jordan, T (2008, November) Opportunities for International Collaboration in Earthquake System Science. In Science as a Gateway to Understanding: International Workshop Proceedings, Tehran, Iran National Academies Press, USA, p.101.

40. Fig OS (2010) Rapid Urbanization and Mega Cities: The Need for Spatial Information Management.

41. Stakhiv EZ (2012) Future Prospects for Water Management and Adaptation to Change. In Toward a Sustainable Water Future: Visions for 2050 pp. 329-340.

42. Ellul C, Zlatanova S, Rumor M, Laurini R (2013) Urban and Regional Data Management: UDMS Annual 2013. Crc Press, USA.

43. Baier K, Mataré V, Liebenberg M, Lakemeyer G (2015) Towards integrated intentional agent simulation and semantic geodata management in complex urban systems modeling. Computers, Environment and Urban Systems 51: 47-58.

44. Tokody D, Schuster, G (2016) Driving Forces Behind Smart City Implementations-The Next Smart Revolution. Journal of Emerging research and solutions in ICT 1(2): 1-16.

45. Shen Z, Li M (2018) Big Data Support of Urban Planning and Management. Springer.

46. Reeves. H (2015) Urban geology-the foundation for cities. British Geological Survey p.11.

47. Ehteshami-Moinabadi M (2006) Geological Data for Urban Development and Geohazards Prevention. National Geoscience Database of Iran p.50.

48. Culshaw MG, Price SJ (2011) The 2010 Hans Cloos lecture. Bulletin of Engineering Geology and the Environment 70(3): 333-376.

49. Ehteshami-Moinabadi M (2016) Surface fault rupture hazard in the Pardis Town, Tehran Province: regarding fault setback in urban development. Journal of Advanced Applied Geology 6 (19): 48-62.

50. Ehteshami-Moinabadi M (2015) Modern faulting and surface rupture hazard in the Qods and Pardisan towns (Qom) 7th International Conference on Seismology \& Earthquake Engineering. IIEES. Tehran. 